schiedene Vortheile; die Arbeit des Relais bei microphonischchronographischer Registrirung ist nur bei stark schlagenden Uhren eine sichere. Jedoch ist es für beide Einrichtungen nothwendig, durch eine Reihe von Vorversurhen die für jeden individuellen Fall beste Art der Microphone und den vortheilhaftesten Platz zu ihrer Anbringung an die Uhr heraus zu finden. Ich erwähne noch, dass Schaltbretter von der oben angeführten Construction mit den nöthigen Microphonen, Telephonen, Relais, Rheostat, Boussole etc. von der hiesigen * Société Genéroise pour la construction d'instruments de physique" fertig geliefert werden.

Genf I 882 August 12.

\title{
Probable times of the four contacts in the coming transit of Venus.
}

\section{By Prof. S. Nerecomb.}

The comparison of different tabular times of contact of Venus with the sun given by Dr. Hilfiker in number 2448 of the A. N. suggests the completion of the comparison by adding the predictions of the American Ephemeris together with the probable actual corrections to the times. It is to be remarked however that these times are derived, not from the tables of Le Verrier, but from Hansen's tables of the sun and Hill's tables of Venus. The following are the tabular times of the principal phases thus obtained, to which are appended the times from Le Verrier's tables. These are the means of the two results from the Nautical Almanac and Berliner Jahrbuch, which are adopted because these means correspond closely to Bessel's semidiameter of the sun, which is adopted in the American Ephemeris.

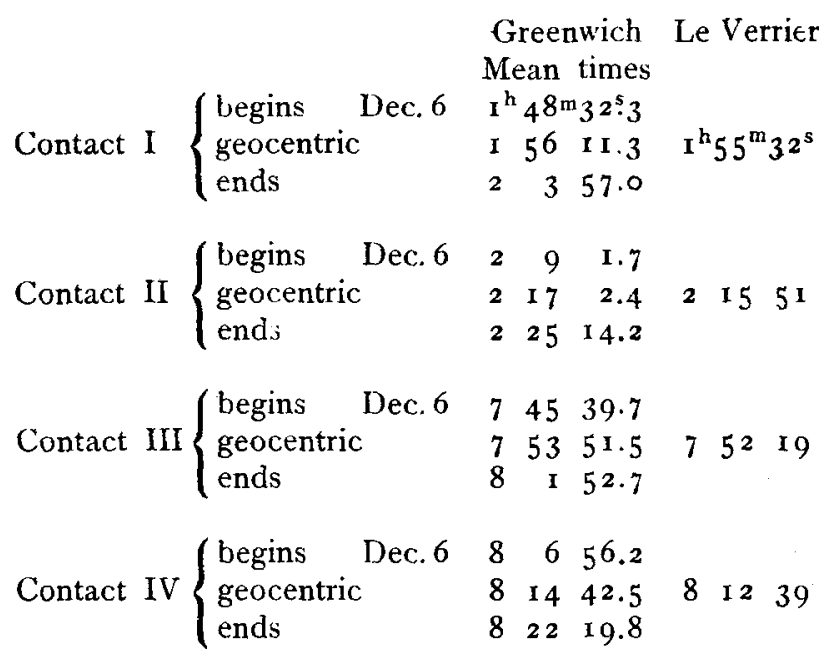

To estimate the corrections which will probably be required both to these times and to those of the other ephemerides we remark that the following corrections to the right ascension and declination of Venus relative to that of the sun were derived from the American photopraphs of 1874 by Mr. D. P. Todd. (Am. Journal of Science, June, r88 r.)

$$
\begin{aligned}
& \Delta\left(\alpha-\alpha^{\prime}\right)=+\mathrm{I} " \mathrm{I} 2 \\
& \Delta\left(\delta-\delta^{\prime}\right)=+2.08
\end{aligned}
$$

As the tabular errors tend to increase with time these corrections will probably be one fifth greater in 1882 which will make them as follows:

$$
\Delta\left(\alpha-\alpha^{\prime}\right)=+\mathrm{I}^{\prime \prime} 3 ; \Delta\left(\delta-\delta^{\prime}\right)=+2 \cdot 5 .
$$

On the other hand, a cumparison of the Ephemerides in the Nautical Almanac with the American Ephemeris shows the following corrections to be applied to the positions of Venus and the sun derived from Le Verrier's tables to reduce them to the tables of Hill and Hansen respectively.

$$
\begin{array}{ll}
\Delta \alpha=+5.9 & \Delta \delta=+0.9 \\
\Delta \alpha^{\prime}=-0.2 & \Delta \delta^{\prime}=+0.3 .
\end{array}
$$

We conclude therefore that the corrections which will probably be required to the relative positions of Venus and the sun given by Le Verrier's tables are:

$$
\Delta\left(\alpha-\alpha^{\prime}\right)=+7{ }^{\prime \prime} ; \Delta\left(\delta-\delta^{\prime}\right)=+3 \cdot 7 .
$$

The following are the resulting corrections to the four times of contact.

$$
\begin{aligned}
& \text { Contact I }+20^{\mathrm{s}} \text {, whence I }=\mathrm{I}^{\mathrm{h}} 55^{\mathrm{m}} 5 \mathrm{2}^{\mathrm{s}} \text { G. M. T. } \\
& \text { II }+ \text { I3 II }=2164 \\
& \text { III }+153 \quad \text { III }=75452 \\
& \text { IV }+145 \quad \text { IV }=8 \text { I5 } 4
\end{aligned}
$$

I beg leave to express the earnest hope that such European observers as can practice before hand on suitably arranged artificial transits will not fail to observe carefully the first contact. As I have several times stated, experience seems to show that if the observer is properly prepared this contact is subject to as little doubt than any of the other three. In order to observe it well the observer should commence looking for it at the proper point just about on e minute before the tabular time of beginning as given on the charts in the American Ephemeris. It is intended to distribute these charts widely before the transit.

Washington 1882 Aug. 28 . Simon Nezcomb.

In halt zu Nr. 2455. H. Bruns. Beobachtungen auf der Universitäts-Sternwarte zu Leipzig. 97. - M. Wilhelm Meyer. Ueber die micro-telephonische Einrichtung der Sternwarte zu Genf. 105. - Simon Nezucomb. Probable times of the four contacts in the corning transit of Venus. III. 